Case Reports

\title{
Impacts of Biogas Digestate on Crop Production and the Environment: A Bulgarian Case Study
}

\author{
${ }^{1}$ Nicholas Kathijotes, ${ }^{2}$ Vera Petrova, ${ }^{2}$ Elena Zlatareva, \\ ${ }^{2}$ Viktor Kolchakov, ${ }^{2}$ Svetla Marinova and ${ }^{2}$ Plamen Ivanov \\ ${ }^{1}$ Cyprus University of Technology, Limassol 3603, POB 50329, Cyprus \\ ${ }^{2}$ Institute of Soil Science Agrotechnology and Plant Protection, “'N. Poushkarov”' Sofia 1080, 7 Shosse Bankya Str, Bulgaria
}

\author{
Article history \\ Received: 26-12-2014 \\ Revised: 26-02-2015 \\ Accepted: 26-02-2015 \\ Corresponding Author: \\ Nicholas Kathijotes \\ Cyprus University of Technology, \\ Limassol 3603, POB 50329, \\ Cyprus \\ Email: nkathijotes@gmail.com
}

\begin{abstract}
The water-energy nexus reveals that large amounts of energy is stored in used water and can be used as an energy source. Anaerobic fermentation is an excellent ecological waste treatment and a way of producing low cost electrical and thermal energy. By using digestate resulting from biogas production instead of synthetic fertilizers derived from natural gas, we can save energy, cut consumption of fossil fuels and reduce our carbon footprint. The aim of this study then is to determine the effect of digestate on the yield and quality of crop production as well as its effect on the immediate environment. A ratio of raw materials in biogas, pig manure and vegetable wastes of 70:30 was used on lettuce as an indicator culture. The studies were carried out on two different soil types. Digestate was applied at various percentages, tested with untreated soil as control. The results are encouraging indicating that digestate as a biomass is rich in macro and micronutrients and can be used in agriculture for the improvement of soil fertility.
\end{abstract}

Keywords: Digestate, Biogas, Anaerobic Fermentation, Sustainable Energy

\section{Introduction}

In view of the current energy conservation needs, the enhancement as well as the promotion of all renewable energy sources becomes an absolute necessity. In recent years there has been increased interest for biogas production from organic waste (Zaharinov, 2011). Currently, potential raw materials for biogas production are underutilized. Their improper processing or deposition often leads to pollution of the environment. In Bulgaria there are still no installations for biogas production.

Anaerobic Fermentation (AF) is a microbiological process for the decomposition of organic matter in the absence of oxygen and is a process characteristic to many natural environments (Galabova et al., 2003). Nowadays AF is used mainly for the production of biogas in airtight tanks-reactor, usually called bioreactors (Schink, 2001). A wide range of microorganisms are involved in this anaerobic process-since main end products are biogas and digestate. Biogas is a combustible gas containing methane, carbon dioxide and small amounts of other gases as well as small amount of other elements (Simeonov et al., 2012; Zaharinov, 2013; Rychtera and Ionas, 1983).

During the anaerobic fermentation for biogas production a secondary biomass is also produced known as digestate. Several studies have found that digestate is a nutrient-rich substance produced by anaerobic digestion that can easily be used as fertilizer. It consists of leftover indigestible material and dead microorganisms cells, with the volume of digestate ranging around $90-95 \%$ of what was initially fed into the digester. Anaerobic digestion reduces the Organic Matter (OM) content of animal slurries and manures and although the digestate has equal amounts of total nitrogen, it has a higher ammoniacal content and therefore provides nitrogen to plants in a more readily available form, similar to that of inorganic fertilisers (Moeller and Stinner, 2009).

By using digestate derived from natural gas instead of synthetic fertilizers, can save energy, cut consumption of fossil fuels and reduce our carbon footprints (Shaffer and Ma, 2001; Marinova et al., 2012; Baykov et al., 2007). Great care however should be exercised as high $\mathrm{Cu}$ and $\mathrm{Zn}$ concentrations in 
digestates from co-digestion of pig and cattle slurry feedstock could jeopardize the sustainability of agricultural soils and high $\mathrm{Mn}$ concentrations in digestates can induce $\mathrm{Mn}$ toxicity in agricultural soils, upon repeated applications (Nkoa, 2014). The legislative trends in the field of wastes management are based on integrated management, adding value to these byproducts; thus, digestate addition to soil-resulting in benefits for agriculture and/or ecological improvement-is considered an appropriate option (Directive, 2008). For the sustainable recycling of digestate in agriculture, they must satisfy certain quality characteristics such as stability and hygiene (BIS, 2010).

The interest of farmers associated with utilization of digestate is related to the lack of organic sources in our country, imbalance of organic matter in Bulgarian soils and the availability of large quantities of organic waste nationwide. The aim of this study then is to establish the potential of digestate for use in agricultural practice and its impact on the yield and quality of crop production at the ratio of the raw materials input into biogas pilot plant-pig manure and market waste (fruits and vegetables), 70:30. The material for our study was provided by the model installation for biogas production of the BAS Institute of Microbiology-Sofia. The digestate ratio 70:30 resulted from experiments by above institute as the most appropriate.

\section{Materials and Methods}

\section{Planning and Conducting the Vegetation Experiments}

In order to establish the most optimal mixture values various vegetation experiments with different mixture proportions were performed. These experiments can also establish the most appropriate and efficient application levels at field conditions (Demirbas, 2006).

Vegetation experiments were conducted using digestate from a model installation for biogas production with raw material comprising of pig manure and vegetable market wastes at a ratio of $70 \%$ : $30 \%$. Experiments were conducted on two soil types, Fluvisols from the area of Kubratovo and Vertisols from the area of Bozhurishte. Soil types were selected as they are among the most popular in the area of the biogas plant.

The following variants were tested: Control-clean soil, control-soil with mineral fertilization and other variants with $5,15,25$ and $35 \%$ of digestate by soil weight.

The variants with mineral fertilization were included in order to provide comparison of the used digestate, which is organic matter (gradually mineralized) to the mineral fertilization (easily assimilated form).

The lettuce (variety Gentilini) was planted as a test crop. For establishment of content of macro and micro nutrients and cation exchange capacity digestate and soil types were analyzed before the experiment.

\section{Methods Used for the Determination of the Yield and Analysis of Soil and Crop Production}

Post-harvest crop yield was recorded and the information was subjected to mathematical and statistical analysis.

The plant production is analyzed for basic content of macro and micro elements and some heavy metals by standard methods used in ISSAPP, "N. Poushkarov", in ISO accredited laboratories. [The equipment is Flame photometer/JENWAY PFP7/-K and $\mathrm{Na}$ Atomic Absorption Spectro photometer/Perkin-Elmer/-heavy metals, $\mathrm{Ca}, \mathrm{Mg}$. The reagents are chemically pure for analysis supplied from MERK]:

- Total nitrogen-Kjeldahl,

- Microelements-method of Hess with atomicabsorption spectrophotometer

- Ammonium and nitrate nitrogen-colorimetrically

- Mobile forms of phosphorus-colorimetrically by a modification of the method of P. Ivanov

- Mobile forms of potassium-with a flame photometer

- Total content of heavy metals-aqua regia method

- Mobile forms of microelements (heavy metals)EDTA-method

- $\quad \mathrm{pH}\left(\mathrm{H}_{2} \mathrm{O}, \mathrm{KCl}\right)$-potentiometrically

- Mechanical composition-pipette method with dispersant-sodium pyrophosphate, in Kaczynski

- Hygroscopic humidity-a thermostatically-weight method

- Soluble salts-weight method

- Electrical conductivity-conductometrically

\section{Results and Discussion}

\section{Characterization and Evaluation of Digestate Used in Vegetation Experiments}

Agronomic and environmental characteristics of digestate obtained from $70 \%$ pig manure: $30 \%$ fruit and vegetable waste is shown on Table 1.

The data show the high values in macro and microelements and can be used in agricultural practices as an improver of the soil properties and crop yield.

The content of the common forms of nutrients-nitrogen, phosphorus and potassium are respectively 10,80, 7,67 and $9,02 \%$ in absolute dry matter. Based on the dry matter content, reported in digestate $(1 \%)$ the real values of total nitrogen were $0,11 \% ; 0,08 \%$ total phosphorus and $0,099 \%$ total potassium. The $\mathrm{pH}$ activity is neutral- 7.62.

The content of heavy metals also shown in Table 1, show values under the Maximum Allowable Concentration (MAC) and digestate poses no hazard for use in agriculture 
Table 1. Chemical and agrochemical characteristics of digestate from vegetative experiments

\begin{tabular}{llll}
\hline & $70: 30$ pig manure: & & $70: 30$ pig manure: \\
Elements & Markets waste & Element & Markets waste \\
\hline $\mathrm{pH}-\mathrm{H}_{2} \mathrm{O}$ & 7,62 & Mobile $\mathrm{P} \%$ & 1,25 \\
Moisture \% & 98,9 & Mobile K \% & 0,1 \\
Dry residue \% & $\mathrm{S}(\mathrm{as} \mathrm{SO}) \%$ & $<5,0$ \\
Organic $\mathrm{C} \%$ & 24,1 & $\mathrm{As} \mathrm{mg} / \mathrm{kg}$ & $<1,0$ \\
Total $\mathrm{P}_{2} \mathrm{O}_{5} \%$ & 7,67 & $\mathrm{Cd} \mathrm{mg} / \mathrm{kg}$ & 13 \\
Total $\mathrm{N} \%$ & 10,8 & $\mathrm{Cr} \mathrm{mg} / \mathrm{kg}$ & 26 \\
Total $\mathrm{K}_{2} \mathrm{O} \%$ & 9,02 & $\mathrm{Ni} \mathrm{mg} / \mathrm{kg}$ & 411 \\
Total $\mathrm{CaO} \%$ & 7,6 & $\mathrm{Cu} \mathrm{mg} / \mathrm{kg}$ & 1409 \\
Total $\mathrm{MgO} \%$ & 2,89 & $\mathrm{Zn} \mathrm{mg} / \mathrm{kg}$ & 8 \\
Mobile $\mathrm{N}-\mathrm{NH}_{4} \%$ & 5,48 & $\mathrm{~Pb} \mathrm{mg} / \mathrm{kg}$ & $<1$ \\
Mobile $\mathrm{N}-\mathrm{NO}_{3} \%$ & 0,53 & $\mathrm{Hg} \mathrm{mg} / \mathrm{kg}$ & \\
\hline
\end{tabular}

The data on chemical composition and physicochemical properties of digestate show that it can be a serious source of important plant nutrients such as nitrogen, phosphorus, potassium, magnesium, calcium, iron, sodium, etc.

\section{Characterization and Evaluation of Experimental Soils Types}

\section{Agrochemical Physical-Chemical Characteristics of Fluvisol from Kubratovo}

Data from the above agrochemical analysis show that the soil is very well supplied with mobile phosphorus (23,2 $\mathrm{mg} \mathrm{P}_{2} \mathrm{O}_{5} / 100 \mathrm{~g}$ soil) well preserved with mobile potassium $\left(27,4 \mathrm{mg} \mathrm{K} \mathrm{K}_{2} \mathrm{O} / 100 \mathrm{~g}\right.$ soil) and mineral nitrogen in dominant ammonium form.

Conductivity is low and amount of soluble salts is also very low. The total amount of heavy metals in the soil is below MAC (Table 2). Ganev and Arsovamethods (1980) method is a precise and rapid method for determining the aggregate cation exchange capacity of soil, the strongly acid and slightly acid exchange positions of the soil adsorbent, the more important exchange cation with acid as well as basic actions are developed. The data obtained is coherent and provides possibility in determining the exact nature, size and topography of the more important acid, salt and buffer adsorption systems on the surfaces of the soil adsorption, which are characteristic of the cation exchange taking place and consequently type of cation exchange between the roots of plants and the soil.

Exchangeable Al-treated with a neutral base buffer salt $1 \mathrm{n} \mathrm{CaCl} 2$ and titrate with $0,04 \mathrm{n} \mathrm{NaOH}$

Exchangeable $\mathrm{Ca}$ and $\mathrm{Mg}$-desorbent buffer solution (1n NaOOCCH3. 3H2O+C4H4O4) with $\mathrm{pH} 8,25$ determined by EDTA.

A physicochemical characterization of soils, used in vegetation experiments was also made. Data on Fluvisols is presented in Table 3. According to the constitution bases, when the bases are $<$ Tca (T 8.2\%) and $\mathrm{pH}<6$ the soil is podzolic. According to the buffer systems the soil is medium acid and the ion exchange capacity ( $\mathrm{T} 8.2=$ $35 \mathrm{~g}$ soil meqv. /100) define it as medium colloidal. The predominant clay minerals determine soil as montmorillonite-illite $\left(81.43 \% \quad \mathrm{~T}_{\mathrm{CA}}=8.2 \mathrm{~T}\right)$ with evolution to Illite-montmorillonite (base $=80.29 \%$ ).

Physical and mechanical properties of Fluvisol (Table 4) show that fraction $<0,001$ dominates.

\section{Agrochemical and Physico-Chemical Characteristics of Vertisols in the Region of Bojurishte}

Soil from Bojurishte region-Sofia that is provided for vegetation experiment is classified as Smolnitsa according to the Bulgarian Soil Classification, which correspond to Vertisol in the World Reference Base for Soil Resources (IUSS, 2006).

Data from agrochemical analysis of the soil show that it is very well supplied with mobile potassium- 36, 92 $\mathrm{mg} \mathrm{K}_{2} \mathrm{O} / 100 \mathrm{~g}$ soil and very low, almost poor in the plants absorbable phosphorus- $0,22 \mathrm{mg} \mathrm{P}_{2} \mathrm{O}_{5} / 100 \mathrm{~g}$ soil.

Mineral nitrogen is in predominance of ammonium form. The amount of soluble salts is very small due to the low conductivity. The total amount of heavy metals is below the limit (Table 2).

Data for physical and chemical characteristics of the soil is presented in Table 5. The ranges of variation of the magnitude of cation sorption capacity $\left(\mathrm{T}_{8,2}\right)$ and the average percentage of strong $\left(\mathrm{T}_{\mathrm{CA}}\right)$ and weak $\left(\mathrm{T}_{\mathrm{A}}\right)$ atsidoid is determined using the Ganev and Arsova method.

Constitution bases soil (A horizon) with $\mathrm{pH}=6.1$, bases $=\mathrm{T}_{\mathrm{CA}}$ confirms that the soil is leached. According to the acid and buffer systems, Vertisol is a weak acid (A horizon). Colloidal reactivity $\left(\mathrm{T}_{8,2}=44\right.$, meqv/100 g) shows that the soil is poorly colloid. The prevalent clay mineralogy $\left(\mathrm{T}_{\mathrm{CA}}=43.86\right.$ meqv/100 g) determine soil as montmorillonite ilite.

It was also determined the mechanical composition of the Vertisol. The results are presented in Table 6. The data shows that dominated participation have a size fraction less than 0.001 (finest fraction). 
Nicholas Kathijotes et al. / American Journal of Environmental Sciences 2015, 11 (2): 81.89 DOI: 10.3844/ajessp.2015.81.89

Table 2. Chemical analysis of Vertisol and Fluvisol of the vegetation experiments

\begin{tabular}{|c|c|c|c|c|c|}
\hline Elements & Vertisols & Fluvisol & Elements & Vertisols & Fluvisol \\
\hline $\mathrm{pH}-\mathrm{H}_{2} \mathrm{O}$ & 6,1 & 5,5 & Exchange $\mathrm{Mg} \mathrm{mg} / 100 \mathrm{~g}$ & 108 & 57 \\
\hline $\mathrm{pH}-\mathrm{KCl}$ & - & 5,5 & Conductivity $\mathrm{mS} / \mathrm{cm}$ & 0,042 & 0,077 \\
\hline Total N \% & 0,12 & 0,21 & Water soluble salts $\mathrm{g} / 100 \mathrm{~g}$ & 0,013 & 0,024 \\
\hline Total $\mathrm{Ca} \%$ & - & 0,14 & As $\mathrm{mg} / 100 \mathrm{~g}$ & $<1$ & $<1$ \\
\hline Total Mg \% & - & 0,58 & $\mathrm{Cd} \mathrm{mg/100} \mathrm{g}$ & $<1$ & $<1$ \\
\hline Total Fe $\%$ & 2,77 & 3,51 & $\mathrm{Cu} \mathrm{mg/100} \mathrm{g}$ & 185 & 210 \\
\hline Total P \% & - & 0,14 & $\mathrm{~Pb} \mathrm{mg} / 100 \mathrm{~g}$ & 2 & 42 \\
\hline $\mathrm{N}-\mathrm{NH}_{4} \mathrm{mg} / \mathrm{kg}$ & 8,2 & 11,8 & $\mathrm{Ni} \mathrm{mg/100} \mathrm{g}$ & 22 & 18 \\
\hline $\mathrm{N}-\mathrm{NO}_{3} \mathrm{mg} / \mathrm{kg}$ & 5,8 & 7,1 & $\mathrm{Zn} \mathrm{mg/100} \mathrm{g}$ & 1170 & 132 \\
\hline Mobile $\mathrm{P}_{2} \mathrm{O}_{5} \mathrm{mg} / 100 \mathrm{~g}$ & 0,22 & 23,2 & $\mathrm{Cr} \mathrm{mg} / 100 \mathrm{~g}$ & 7 & 11 \\
\hline Mobile $\mathrm{K}_{2} \mathrm{O} \mathrm{mg} / 100 \mathrm{~g}$ & 36,9 & 27,4 & Humus \% & 3,36 & - \\
\hline Exchange $\mathrm{Ca} \mathrm{mg} / 100 \mathrm{~g}$ & 696 & 430 & & & \\
\hline
\end{tabular}

Table 3. Cation exchange capacity and base saturation in studied Fluvisol

\begin{tabular}{|c|c|c|c|c|c|c|c|c|c|}
\hline \multirow[b]{2}{*}{ Materials } & & \multirow[b]{2}{*}{$\mathrm{pH} / \mathrm{H}_{2} \mathrm{O}$} & \multicolumn{7}{|c|}{ meqv/100 g. } \\
\hline & & & $\mathrm{T}_{8,2}$ & $\mathrm{~T}_{\mathrm{CA}}$ & $\mathrm{T}_{\mathrm{A}}$ & Exch. $\mathrm{H}_{8,2}$ & Exch. $\mathrm{Al}+\mathrm{H}$ & Exch. Ca & Exch. $\mathrm{Mg}$ \\
\hline Soil & & 5,5 & 35,0 & 28,5 & 6,5 & 6,9 & 0,4 & 24,0 & 3,9 \\
\hline $\begin{array}{l}\mathrm{T}_{\mathrm{CA}} \\
\% \mathrm{~T}_{8,2}\end{array}$ & $\mathrm{~T}_{\mathrm{A}}$ & Exch. $\mathrm{H}_{8,2}$ & Exch. Al & Exch. $\mathrm{Ca}$ & Exch. Mg & \multicolumn{4}{|c|}{ base saturation $\%$} \\
\hline 81,43 & 18,57 & 19,71 & 1,43 & 68,57 & 10,86 & \multicolumn{4}{|l|}{80,29} \\
\hline
\end{tabular}

Table 4. Mechanical composition of Fluvisol from the vegetation experiments

\begin{tabular}{|c|c|c|c|c|c|c|c|c|}
\hline \multirow[b]{2}{*}{ Variants } & \multicolumn{8}{|c|}{ Particle size (mm) } \\
\hline & Amount $>1$ & $1-0.025$ & $0.25-0.05$ & $0.05-0.01$ & $0.01-0.005$ & $0.005-0.001$ & $<0.001$ & Amount $<0.01$ \\
\hline Soil & 0.0 & 16,7 & 19,73 & 13,72 & 15,04 & 6,71 & 28,10 & 49,85 \\
\hline
\end{tabular}

Table 5. Cation exchange capacity and base saturation in studied Vertisol

\begin{tabular}{|c|c|c|c|c|c|c|c|c|c|}
\hline \multirow{2}{*}{\multicolumn{2}{|c|}{ Materials }} & \multicolumn{8}{|c|}{ meqv/100 g. } \\
\hline & & $\mathrm{pH} / \mathrm{H}_{2} \mathrm{O}$ & $\mathrm{T}_{8,2}$ & $\mathrm{~T}_{\mathrm{CA}}$ & $\mathrm{T}_{\mathrm{A}}$ & Exch. $\mathrm{H}_{8,2}$ & Exch. $\mathrm{Al}+\mathrm{H}$ & Exch. Ca & Exch. Mg \\
\hline Soil & & 6,1 & 50,7 & 43,86 & 6.9 & 3,9 & 0,0 & 34,7 & 9,04 \\
\hline $\begin{array}{l}\mathrm{T}_{\mathrm{CA}} \\
\% \mathrm{~T}_{8,2}\end{array}$ & $\mathrm{~T}_{\mathrm{A}}$ & Exch. $\mathrm{H}_{8,2}$ & Exch. Al & Exch. $\mathrm{Ca}$ & Exch. Mg & \multicolumn{4}{|c|}{ base saturation $\%$} \\
\hline 86,39 & 13,61 & 7,69 & 0,0 & 72,39 & 17,89 & \multicolumn{4}{|l|}{92,31} \\
\hline
\end{tabular}

Table 6. Mechanical composition of Vertisols for vegetation experiments

\begin{tabular}{|c|c|c|c|c|c|c|c|c|}
\hline \multirow[t]{2}{*}{ Variants } & \multicolumn{8}{|c|}{ Particle size $(\mathrm{mm})$} \\
\hline & Amoun $\mathrm{t}>1$ & $1-0.25$ & $0.25-0.05$ & $0.05-0.01$ & $0.01-0.005$ & $0.005-0.001$ & $<0.001$ & Amoun $\mathrm{t}<0.01$ \\
\hline Soil & 0.0 & 1,8 & 9,8 & 13,0 & 11,5 & 8,8 & 53,3 & 73,6 \\
\hline
\end{tabular}

\section{Plants Development during Vegetation Process}

As noted above, vegetation experiments were conducted with digestate from biogas production in pilot installation together with raw materials in a ratio $70 \%$ pig manure: $30 \%$ vegetable waste (Simeonov et al., 2012).

Vegetation experiments were set on 31 October 2011 on the already mentioned two soil types (Fluvisols and Vertisols). Sowing of lettuce was carried out. Plants germinated normal on 10 November 2011. 20 days later lettuce was thinned. Daily watering of plants, according to the Field Capacity (FC) was fulfilled. 46 days after sowing the plants and different variants were photographed on both soil types.

\section{Lettuce}

\section{Yield and Chemical Analysis of Lettuce Plant Production}

Vegetation experiments show that lettuce develops normally on both soil types. The obtained data from lettuce yield on Fluvisol (Fig. 1) and leaching Vertisol (Fig. 2) show that quantity of biomass is higher on the first soil type for all variants. 


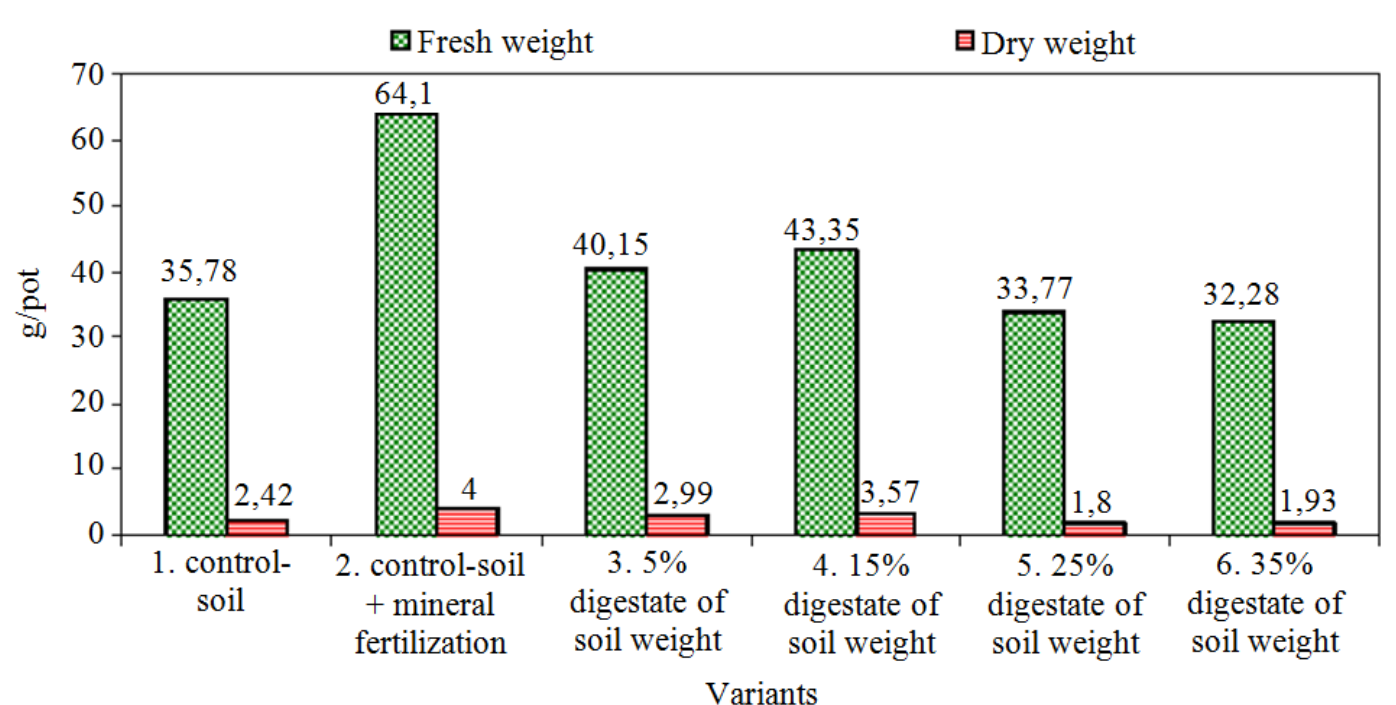

Fig. 1. Yield of lettuce from Fluvisol on experiments with digestate

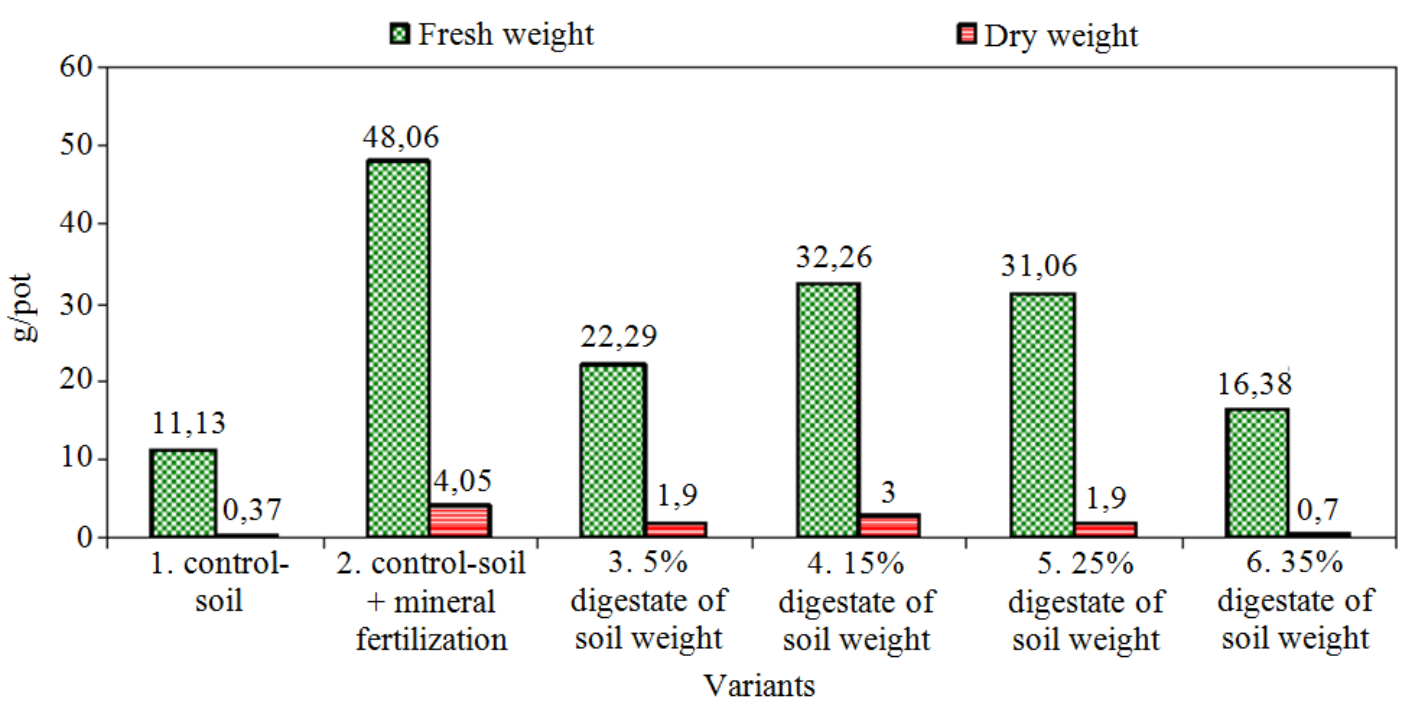

Fig. 2. Yield of lettuce from Vertisol on experiments with digestate

The high value of lettuce yield on Fluvisol is probably due to the very good soil preservation with $\mathrm{N}$, $\mathrm{P}$ and $\mathrm{K}$. The trend in yield by increasing the amount of digestate for both soil types is similar. The best lettuce developing is observed in variants with mineral fertilization and the yield is highest. Biomass of lettuce in control variant (clean soil) remains low compared to other variants and it is similar in both soil types. For variants with digestate the largest biomass was measured in variants with $15 \%$ digestate compared to control variant. High doses of digestate have suppressive effects on plant development and yield probably due to excessive high levels of digestible nitrogen, phosphorus and potassium. Higher doses of digestate obtain the soil compaction, which affects the optimal development of lettuce root system. On the other hand digestate values larger than $15 \%$ are not environmentally friendly and cost effective. The highest yield of lettuce in both soils was obtained with mineral fertilization variants- $4 \mathrm{~g} /$ pot in Fluvisol and $4.05 \mathrm{~g} /$ pot-Vertisols. The differences between each variant are greater than Less Permissible Difference (LPD) $0.1 \%$. In digestate variants, the maximum of yield is in $15 \%$ digestate by weight of soil. The difference between yields from variants of Fluvisol is statistically proven (LPD 1\%) and the Vertisols-in (LPD 0, 1\%). There is a tendency to reduce yield at further increasing the amount of introduces digestate (with LPD 0, 1\%).

After lettuce harvesting some analyses for content of basic macro and microelements and heavy metals were 
made. The results of chemical analysis of plant production are presented in Table 7 and 8 .

The content of total nitrogen in plants varies between 1.40 and $2.40 \%$ on Fluvisol and from 0.83 to $1.40 \%$ on Vertisols. These values are comparable with data from previous studies (Mitova and Marinova, 2012) with enriched vermiculite on the same soil types and the same variety of lettuce.

In Fluvisol with increasing digestate amount, the phosphorus in plants is not changed, potassium increased slightly, while calcium and magnesium is varying (Table 7).

Vertisols for the content of all nutrients expressed no clear trend with increasing amount of digestate, the concentrations in different variants slight vary (Table 8).

Analyses for content of microelements $\mathrm{Cu}, \mathrm{Zn}$ and $\mathrm{Mn}$ in plant production show that they are in optimal range for the species.

The iron content in plant tissues at the end of the study have high values in Vertisols (from 850 to 2400 $\mathrm{mg} / \mathrm{kg}$ ) and from 800 to $1400 \mathrm{mg} / \mathrm{kg}$ in Fluvisol. Regardless of increased amounts of iron visible depression in lettuce is not noticeable.

\section{Chemical and Agrochemical Characteristic of Fluvisol from Kubratovo after Lettuce Harvesting}

Agrochemical analysis of soil, after harvest lettuce show that increasing of digestate amount significantly leads to increased absorbable phosphorus for plants (Table 9).

Higher level of supply absorb phosphorus has the variant with $35 \%$ added digestate, which causes a decrease in yield. The degree of movable potassium increases with increasing of digestate amount in variants. In $35 \%$ digestate the potassium content reaches $45,2 \mathrm{mg} \mathrm{K}_{2} \mathrm{O} / 100 \mathrm{~g}$ soil and it shows very high degree of supply with this nutrient. The amount of mineral nitrogen was also increased with increasing dose of digestate. This is at the expense of a large increase of nitrogen from $16,83 \mathrm{mg} / \mathrm{kg} \mathrm{N}-\mathrm{NO}_{3}$ var. 1 up to $45,8 \mathrm{mg} / \mathrm{kg} \mathrm{N}-\mathrm{NO}_{3}$ for var.6. The change of ammonia form of mineral nitrogen is weak and variable, but generally mineral nitrogen has very high values (Table 9).

After harvesting the lettuce analyses of conductivity and presence of soluble salts in variants, show increasing amount of added compost gradually increasing conductivity and the amount of water-soluble salts, but they are within the limits of not salty soils. The highest values have variant 2 , with incorporated mineral $\mathrm{N}, \mathrm{P}, \mathrm{K}$ fertilizers (Table 10).

Chemical and Agrochemical Characteristic of Vertisols in the Region of Bojurishte after Lettuce Harvesting

Studies on agrochemical characteristics of soil after harvesting the lettuce found that increasing of digestate dose leads to smoothly increasing of absorbable phosphorus for plants. The highest dose of digestate is $\mathrm{P}_{2} \mathrm{O}_{5} / 10014,16 \mathrm{mg}$ g soil (Table 11). In variant with $35 \%$ digestate is achieved moderate supply of absorbable phosphorus. The degree of movable potassium in Vertisols is very good. In the variants with the highest amount of digestate content reaches $10,1 \mathrm{mg} \mathrm{K}_{2} \mathrm{O} / 100 \mathrm{~g}$ soil and it can lead to depression in yield. As noted above the amount of mineral nitrogen in non treated soil is high with prevalence of the ammonia form. Significantly increasing of the digestate dose, lead to increasing the amount of nitrate form of mineral nitrogen (Table 11).

Table 7. Chemical characteristic of plant production by lettuce grown on Fluvisol

\begin{tabular}{lllllllllr}
\hline Variants & $\mathrm{N} \%$ & $\mathrm{P} \%$ & $\mathrm{~K} \%$ & $\mathrm{Ca} \%$ & $\mathrm{Mg} \%$ & $\mathrm{Zn} \mathrm{mg} / \mathrm{kg}$ & $\mathrm{Cu} \mathrm{mg} / \mathrm{kg}$ & $\mathrm{Mn} \mathrm{mg} / \mathrm{kg}$ & $\mathrm{Fe} \mathrm{mg} / \mathrm{kg}$ \\
\hline 1. Control & 1,40 & 0,46 & 6,80 & 1,22 & 0,32 & 46 & 10 & 78 & 800 \\
2. Soil + NPK & 2,20 & 0,72 & 7,40 & 1,53 & 0,42 & 53 & 11 & 95 & 1200 \\
3. 5\% digestate & 1,20 & 0,49 & 7,40 & 1,19 & 0,31 & 39 & 11 & 92 & 1650 \\
4. 15\% digestate & 1,30 & 0,46 & 6,40 & 1,44 & 0,45 & 42 & 6 & 98 & 1050 \\
5. 25\% digestate & 2,30 & 0,45 & 8,60 & 1,43 & 0,38 & 50 & 10 & 48 & 1000 \\
6. 35\% digestate & 2,40 & 0,43 & 9,00 & 1,50 & 0,40 & 51 & 13 & 63 & 1400 \\
\hline
\end{tabular}

Table 8. Chemical characteristic of plant production by lettuce grown on Vertisols

\begin{tabular}{lllllllllr}
\hline Variants & $\mathrm{N} \%$ & $\mathrm{P} \%$ & $\mathrm{~K} \%$ & $\mathrm{Ca} \%$ & $\mathrm{Mg} \%$ & $\mathrm{Zn} \mathrm{mg} / \mathrm{kg}$ & $\mathrm{Cu} \mathrm{mg} / \mathrm{kg}$ & $\mathrm{Mn} \mathrm{mg} / \mathrm{kg}$ & $\mathrm{Fe} \mathrm{mg} / \mathrm{kg}$ \\
\hline 1. Control & 0,83 & 0.18 & 5.80 & 1.00 & 0.25 & 35 & 7 & 65 & 850 \\
2. Soil + NPK & 1,40 & 0,43 & 7,50 & 1,18 & 0,28 & 41 & 9 & 67 & 950 \\
3. 5\% digestate & 1,20 & 0,25 & 6,00 & 0,92 & 0,23 & 36 & 7 & 71 & 900 \\
4. 15\% digestate & 1,40 & 0,18 & 6,80 & 0,84 & 0,30 & 48 & 11 & 103 & 2000 \\
5. 25\% digestate & 1,20 & 0,27 & 8,40 & 1,07 & 0,39 & 54 & 10 & 104 & 2500 \\
6. 35\% digestate & 1,40 & 0,26 & 7,50 & 2,40 & 0,47 & 66 & 13 & 120 & 2300 \\
\hline
\end{tabular}


Table 9. Agrochemical characteristic of Fluvisol with variant post-harvest vegetation experiments with lettuce

\begin{tabular}{|c|c|c|c|c|c|}
\hline \multirow[b]{2}{*}{ Variants } & \multirow[b]{2}{*}{$\mathrm{pH} \mathrm{H} \mathrm{H}_{2} \mathrm{O}$} & \multicolumn{2}{|c|}{ Mineral nitrogen $\mathrm{mg} / \mathrm{kg}$} & \multirow[b]{2}{*}{$\mathrm{P}_{2} \mathrm{O}_{5} \mathrm{mg} / 100 \mathrm{~g}$} & \multirow[b]{2}{*}{$\mathrm{K}_{2} \mathrm{O} \mathrm{mg} / 100 \mathrm{~g}$} \\
\hline & & $\mathrm{NH}_{4}$ & $\mathrm{NO}_{3}$ & & \\
\hline 1. Control & 5,8 & 66,70 & 16,80 & 23,20 & 28,40 \\
\hline 2. Soil + NPK & 5,3 & 62,10 & 44,70 & 76,60 & 39,20 \\
\hline 3. $5 \%$ digestate & 5,8 & 66,70 & 28,40 & 26,70 & 32,90 \\
\hline 4. $15 \%$ digestate & 5,9 & 60,90 & 38,90 & 32,30 & 34,00 \\
\hline 5. $25 \%$ digestate & 5,9 & 70,20 & 43,50 & 42,10 & 43,20 \\
\hline 6. $35 \%$ digestate & 6,0 & 52,80 & 45,80 & 50,30 & 45,20 \\
\hline
\end{tabular}

Table 10. Assessment salinity of Fluvisol from vegetation experiments with lettuce with different variants of digestate

\begin{tabular}{lll}
\hline Variants & Conductivity $\mathrm{mS} / \mathrm{cm}$ & Water soluble salts $\mathrm{g} / 100 \mathrm{~g}$ \\
\hline 1. Control & 0,098 & 0,030 \\
2. Soil + NPK & 0,308 & 0,100 \\
3. $5 \%$ digestate & 0,084 & 0,027 \\
4. $15 \%$ digestate & 0,098 & 0,031 \\
$5.25 \%$ digestate & 0,116 & 0,037 \\
$6.35 \%$ digestate & 0,135 & 0,043 \\
\hline
\end{tabular}

Table 11. Agrochemical characteristics of Vertisols after lettuce harvesting

\begin{tabular}{|c|c|c|c|c|c|}
\hline \multirow[b]{2}{*}{ Variants } & \multirow[b]{2}{*}{$\mathrm{pH} \mathrm{H} \mathrm{H}_{2} \mathrm{O}$} & \multicolumn{2}{|c|}{ Mineral nitrogen $\mathrm{mg} / \mathrm{kg}$} & \multirow[b]{2}{*}{$\mathrm{P}_{2} \mathrm{O}_{5} \mathrm{mg} / 100 \mathrm{~g}$} & \multirow[b]{2}{*}{$\mathrm{K}_{2} \mathrm{O} \mathrm{mg} / 100 \mathrm{~g}$} \\
\hline & & $\mathrm{NH}_{4}$ & $\mathrm{NO}_{3}$ & & \\
\hline 1. Control & 6,1 & 49,3 & 13,3 & 0,75 & 45,0 \\
\hline 2. Soil + NPK & 5,6 & 101,5 & 124,7 & 66,13 & 105,0 \\
\hline 3. $5 \%$ digestate & 6,1 & 63,2 & 33,1 & 3,13 & 46,0 \\
\hline $415 \%$ digestate & 6,0 & 58,6 & 55,1 & 6,38 & 51,0 \\
\hline 5. $25 \%$ digestate & 5,9 & 71,3 & 80,6 & 11,63 & 59,0 \\
\hline 6. $35 \%$ digestate & 6,1 & 53,9 & 94,5 & 14,16 & 101,1 \\
\hline
\end{tabular}

Table 12. Evaluation of Vertisols salinity after lettuce harvesting

\begin{tabular}{llll}
\hline Variants & $\mathrm{pH} \mathrm{H}_{2} \mathrm{O}$ & Conductivity $\mathrm{mS} / \mathrm{cm}$ & Water soluble salts $\mathrm{g} / 100 \mathrm{~g}$ \\
\hline 1. Control & 6,1 & 0,042 & 0,013 \\
2. Soil + NPK & 5,6 & 0,406 & 0,130 \\
3. $5 \%$ digestate & 6,1 & 0,084 & 0,027 \\
4. $15 \%$ digestate & 6,0 & 0,098 & 0,031 \\
5. $25 \%$ digestate & 5,9 & 0,116 & 0,037 \\
$6.35 \%$ digestate & 6,1 & 0,135 & 0,043 \\
\hline
\end{tabular}

Analyses were conducted for the electrical conductivity and the presence of soluble salts on all variants after lettuce harvesting. It is found that with increasing amount of imported digestate slightly increases conductivity and quantity of water-soluble salts, but this does not lead to salinization (Table 12). The highest values belong to both indicators, measured for variants with chemical fertilization (Table 12).

\section{Conclusion}

As a result of the experiments performed and the obtained results, we can state the following findings:

- Agrochemical and chemical characteristics demonstrate that digestate as a biomass is rich in macro and micronutrients and can be used in agriculture for the improvement of soil fertility. The content of heavy metals in initial experimental digestate was below the maximum allowable concentration and therefore the soil was not burdened with these polluting elements

- Vegetation experiments demonstrated a positive effect of digestate utilization on the yield and quality of crop production. Results in lettuce under varying doses of biomass indicates that plants showed the best development and quality options with $15 \%$ digestate containing $70 \%$ of pig manure

- The results for total nitrogen, phosphorus, potassium, calcium, magnesium and microelements copper, zinc and manganese in plant production of lettuce are within the normal 
range for the species. Values in iron content were higher in lettuce grown on Vertisols

- Increasing of digestate dose significantly increases plants absorbance of phosphorus and potassium for both soil types. The quantity of mineral nitrogen (nitrate form) also shows increase. The amount of soluble salts in the soil demonstrate a slight increase, which poses no danger for salinization

- Although digestate is generally characterized by non-specific parameters and the content of macrocomponents is relatively well known, further research is required in order to resolve unresolved quality issues as well as other of its possible effects on the immediate environment

\section{Acknowledgement}

The present publication has been prepared with the support of Project № BG051PO001-3.3.06-0042: "Program for Improvement of the Interdisciplinary Training and Raising the Qualification of Young Scientists in the Field of Soil Science and Ecology", which is financed by the Operational Program "Human Resource Development" and the European Social Fund.

\section{Author's Contributions}

Each author contributed equally in the preparation, development and publication of this manuscript.

\section{Ethics}

This article is original and contains unpublished material. The corresponding author confirms that all of the other authors have read and approved the manuscript and no ethical issues involved.

\section{References}

Aiburquerque, J.A., C. de Fuente and M.P. Bernal, 2014. Chemical properties of anaerobic digestates affecting $\mathrm{C}$ and $\mathrm{N}$ dynamics in amended soils. Agric. Ecosyst. Environ., 160: 15-22.

Baykov, B., J. Petkov, K. Kirov, B. Zaharinov and N. Marinova et al., 2007. Exploring the quality of compost as a natural replacement for high energy chemical fertilizers. Environmental assessment of the amount of toxic elements in compost. Ecol, Eng. Environ. Protect., 2: 33-36.

BIS, 2010. Specification for whole digestate, separated liquor and separated fiber derived from the anaerobic digestion of source-segregated biodegradable materials British Standards Institution Publications, PAS 110, London, UK.
Demirbas, A., 2006. Biogas potential of manure and straw mixtures. Energy Sources, 28: 71-78. DOI: $10.1080 / 009083190889672$

Directive, 2008. EC of the European parliament and of the council of 19 November 2008 on waste and repealing certain directives (Waste framework directive, R1 formula in footnote of attachment II). Official J. Eur. Union L, 312: 1-30.

Galabova, D., I. Simeonov, D. Dalev and D. Karakashev, 2003. Research and optimization of the anaerobic digestion of organic wastes. Ecol. Eng. Environ. Protect., 2: 37-43.

Ganev, S. and A. Arsovamethods, 1980. Metods of determining the strongly acid and the slightly acid cation exchange in soil. Soil Sci. Agrochem., 15: 22-33.

IUSS, 2006. World Reference Base for Soil Resources 2006. 2nd Edn., World Soil Resources Reports, FAO, Rome, pp: 128.

Marinova S., S. Mihaylova, E. Zlatareva, R. Toncheva and H. Pchelarova et al., 2012. Effect of digestate from anaerobic co-degistation of wasted fruits and vegetables and swine manure on development of lettuce. Proceedings of the International Conference on Ecology-Interdisciplinary Science and Practice, Oct. 25-26, Sofia, Bulgaria, pp: 493-497.

Mitova, I. and S. Marinova, 2012. Effects of enriched vermiculite on the formation of yield and quality in lettuce. Soil Science and Agricultural Chemistry and Ecology.

Moeller, K. and W. Stinner, 2009. Effects of different manuring systems with and without biogas digestion on soil mineral nitrogen content and on gaseous nitrogen losses (ammonia, nitrous oxides). Eur. J. Agronomy, 30: 1-16.

DOI: $10.1016 /$ j.eja.2008.06.003

Nkoa, R., 2014. Agricultural benefits and environmental risks of soil fertilization with anaerobic digestates: A review. Agronomy Sustainable Dev., 34: 473-492.

Rychtera, M. and J. Ionas, 1983. Biotechnological aspects of biogas production from agricultural wastes. Proceedings of the Biotechnology Symp. of Socialist Countries Bratislava, Apr. 25-29, pp: 455-473.

Schink, B., 2001. Anaerobic digestion concepts, limits and perspectives. Proceedings of the 9th World Congress "Anaerobic Digestion", Sept. 2-6, Antverpen, Belgium, pp: 15-21.

Shaffer, M.J. and L. Ma, 2001. Carbon and Nitrogen Dynamics in Upland Soils. In: Modeling Carbon and Nitrogen Dynamics for Soil Management, Shaffer, M.J., L. Ma and S. Hansen (Eds.), CRC Press, ISBN-10: 1566705290, pp: 11-26. 
Simeonov, I., S. Mihaylova, B. Kalchev, E. Chorukova and S. Marinova, 2012, Study on the anaerobic codigestion of waster fruits and vegetables. Proceedings of the BALWOIS 5th International Conference on Water, Climate and Environment, May 28-Jun. 2, Ohrid, FYROM.

Zaharinov, B., 2011. Waste management through their use of organic matter as a source of energyconversion of established industry boundaries. NBU collection of articles, Ecology.
Zaharinov, B., 2013. Biomass, biogas, compost energy of anthropogenic ecosystems. Environmental biotechnology for the production of biogas and compost utilization. NBU, Sofia. 